\title{
Znaczniki typów odporności pszenicy na Puccinia triticina
}

\author{
Markers of wheat resistance types on Puccinia triticina
}

\section{Przemysław Werecki ${ }^{\bowtie 1}$, Marta Dmochowska-Boguta ${ }^{1}$ Anna Nadolska- Orczyk $^{2}$ Wacław Orczyk ${ }^{1}$}

\author{
${ }^{1}$ Zakład Inżynierii Genetycznej, ${ }^{2}$ Zakład Genomiki Funkcjonalnej, Instytut Hodowli i Aklimatyzacji Roślin — \\ Państwowy Instytut Badawczy, Radzików \\ e-mail: p.werecki@ihar.edu.pl
}

\begin{abstract}
Celem pracy było wskazanie różnic pomiędzy odpornością rasowo-specyficzną i rasowo-niespecyficzną, by ocena odporności polowej badanej linii hodowlanej mogła być uzupełniona o dane wskazujące na typ odporności. Materiałem do badań była pszenica podatna odmiany Thatcher (Tc) oraz 5 linii izogenicznych z genami warunkującymi określony, znany typ odporności. Oceniano typy infekcji w siewkach i roślinach dorosłych. Na podstawie obserwowanych różnic można dokonać wstępnej selekcji roślin z odpornością rasowo-niespecyficzną typu APR.

Slowa kluczowe: odporność roślin, Puccinia triticina, APR

The aim of the work was to show the differences between racial-specific and racist-non-specific resistance, in order to assess the field resistance of the tested breeding line to be supplemented with data indicating the type of immunity. The material for testing was wheat susceptible of the Thatcher variety (Tc) and 5 isogenic lines with genes conditioning a specific, known type of immunity. Infection types in seedlings and adult plants were assessed. Based on the observed differences, the initial selection of plants with APR-type racially-nonspecific immunity can be made.
\end{abstract}

Key words: plant resistance, Puccinia triticina, APR

Celem pracy było wskazanie różnic pomiędzy odpornością rasowo-specyficzną i rasowo niespecyficzną (odpornością roślin dorosłych APR) po to, aby ocena odporności polowej badanej linii hodowlanej mogła być uzupełniona o dane wskazujące na typ odporności. Materiałem do badań była pszenica podatna odmiany Thatcher $(\mathrm{Tc})$ oraz 5 linii izogenicznych z genami warunkującymi określony, znany typ odporności. Linie TcLr9 i TcLr24 reprezentowały odporność rasowo specyficzną, odpowiednio silną i średnią w stosunku do wybranego izolatu $P$. triticina, linie TcLr12, TcLr22 i TcLr34 reprezentowały odporność rasowoniespecyficzną typu APR. Założono, że obydwa typy odporności oceniane na siewkach i roślinach dorosłych będą różniły się: fenotypową oceną typów infekcji (skala 0-4, wybranymi reakcjami gospodarza (wybuch oksydacyjny, reakcje mikronekrotyczne), profilem interakcji roślina - patogen (obserwowanych w 1,2,4,8 dni po inokulacji (dpi)) (Orczyk i in., 2010) oraz stopniem kolonizacji rośliny przez patogena (czas latencji, wielkość urediniów) (Das i in., 1993). Oceniano typy infekcji w siewkach i roślinach dorosłych. Zaobserwowano różnice typów infekcji pomiędzy siewkami a roślinami dorosłymi w liniach TcLr24 (typy infekcji siewek i roślin dorosłych odpowiednio 2, $0 ;$ ), oraz dla roślin z odpornością typu APR TcLr12, TcLr22 i TcLr34 (odpowiednio 4 i 2; 4 i 2; 3 i 2). Typy infekcji podatnej odmiany Thatcher wyniosły 4 i 4). Interakcję roślina - patogen opisywano poprzez wskazanie obecności struktur patogena - komórek macierzystych haustorium $(\mathrm{KMH})$ i urediniów, natomiast reakcję rośliny stanowiła reakcja mikronekrotyczna oraz akumulacja nadtlenku wodoru $\mathrm{w}$ miejscu infekcji. W siewkach i roślinach dorosłych linii silnie odpornej TcLr9 obserwowano niewielką liczbę $\mathrm{KMH}$, które od 4dpi przestawały być widoczne, nie obserwowano urediniów. Reakcja mikronekrotyczna i akumulacja $\mathrm{H}_{2} \mathrm{O}_{2}$ występowały od 2dpi. W linii średnio odpornej TcLr24 w siewkach obserwowano dużą liczbę KMH oraz średnie uredinia, reakcja mikronekrotyczna i akumulacja $\mathrm{H}_{2} \mathrm{O}_{2}$ były późniejsze o jeden dzień w porównaniu do TcLr9. W roślinach dorosłych nie obserwowano urediniów, natomiast reakcja mikronekrotyczna była obserwowana 2 dni wcześniej niż w siewkach. W siewkach podatnej Thatcher oraz liniach z odpornością APR obserwowano dużą liczbę KMH oraz duże uredinia, reakcja mikronekrotyczna nie była obserwowana, natomiast akumulację $\mathrm{H}_{2} \mathrm{O}_{2}$ zaobserwowano sporadycznie tylko $\mathrm{w}$ aparatach szparkowych. W roślinach dorosłych linii z APR w porównaniu $\mathrm{z}$ Thatcher obserwowano zmniej- 
szoną liczbę $\mathrm{KMH}$, mniejsze uredinia. Reakcja mikronekrotyczna była obecna od 2dpi w większości miejsc infekcyjnych, a akumulacja $\mathrm{H}_{2} \mathrm{O}_{2}$ występowała od 1 do 2dpi w aparatach szparkowych i mezofilu. W liniach, u których wytwarzane były uredinia oceniano czas latencji i mierzono wielkość urediniów. W siewkach czas latencji był podobny w liniach TcLr12, TcLr22TcLr24, TcLr34 oraz kontroli Thatcher. Czas latencji w roślinach dorosłych był dłuższy jak w siewkach (o 4 dni) a dla TcLr34 był dłuższy o 6 dni. Względna wielkość urediniów w siewkach linii TcLr12, TcLr22,TcLr24, TcLr34 w stosunku do linii podatnej Thatcher wyniosła $0.8 ; 1.1 ; 0,3$ i 0,8 . Względna wielkość urediniów w roślinach dorosłych linii TcLr12, TcLr22,TcLr34 wynosiła 0,2; 0,7 i 0,7.
Przedstawione wyniki wskazują, że istnieje wzór interakcji roślina-patogen charakterystyczny dla określonych typów odporności. Na podstawie obserwowanych różnic można dokonać wstępnej selekcji roślin z odpornością rasowo niespecyficzną typu APR.

\section{Literatura}

Das M. K., Rajaram S., Kronstad W. E., Mundt C, C., Singh R. P. 1993. Associations and genetics of 3 components of slow rusting in leaf rust of wheat. Euphytica 68: 99 -109 .

Orczyk W., Dmochowska-Boguta M., Czembor H. J, Nadolska-Orczyk A. 2010. Spatiotemporal patterns of oxidative burst and micronecrosis in resistance of wheat to brown rust infection. Plant Pathology 59: 567 -575 .

Roelfs A. P., Martens J. W. 1988. An international system of nomenclature for Puccinia graminis f. sp. tritici. Phytopathology 78: $526-533$. 